\title{
SELEKSI MIKROBA METANOGENIK MENGGUNAKAN IRRADIASI GAMMA UNTUK PENINGKATAN EFISIENSI PROSES DIGESTI ANAEROB PEMBENTUKAN BIOGAS
}

\author{
M. Yazid, Aris Bastianudin \\ Pusat Teknologi Akselerator dan Proses Bahan BATAN Yogyakarta \\ Jl Babarsari Kotak Pos 6101 ykbb, Yogyakarta 55281
}

Diterima 7 Oktober 2010, diterima dalam bentuk perbaikan 3 Januari 2011, disetujui 4 Januari 2011

\begin{abstract}
ABSTRAK
SELEKSI MIKROBA METANOGENIK MENGGUNAKAN IRRADIASI GAMMA UNTUK PENINGKATAN EFISIENSI PROSES DIGESTI AN-AEROB PEMBENTUKAN BIOGAS. Seleksi mikroba metanogenik menggunakan irradiasi gamma sebagai upaya peningkatan efisiensi proses pembentukan biogas telah dilakukan. Tujuan dari penelitian ini, untuk mendapatkan isolat mikroba metanogenik yang mempunyai konstanta pertumbuhan spesifik $(\mu)$ tinggi sehingga diharapkan dapat diaplikasikan untuk peningkatan efisiensi produksi biogas pada proses digesti anaerob dari kotoran ternak. Sebagai sumber mikroba digunakan sludge yang diambil dari dalam tangki digester instalasi biogas konvensional di dusun Marangan, Bokoharjo, Prambanan, Sleman. Adapun irradiasi dilakukan menggunakan Irradiator Gamma C0-60 dengan variasi dosis 0-25 kGy. Isolasi mikroba dilakukan dalam media pertumbuhan yang mengandung $30 \%$ rumen cair dalam suasana anaerob dengan penambahan campuran gas $80 \% \mathrm{H}_{2}$ dan $20 \% \mathrm{CO}_{2}$. Pengamatan pertumbuhan koloni dilakukan menggunakan sinar ultra violet (UV) gelombang panjang, sedangkan pertumbuhan mikroba ditentukan berdasarkan hasil analisis spektrofotometri dan penentuan gas metan menggunakan gas kromatografi. Dari hasil penelitian ini didapatkan 4 isolat mikroba metanogenik (RB10, RB15, RB20 dan RB25) yang tumbuh pada perlakukan irradiasi dengan dosis 10-25 kGy. Dari hasil identifikasi dapat diketahui bahwa isolat mikroba RB10 dan RB25 merupakan anggota dari genus Methanobacterium sedangkan isolat RB15 dan RB20 masing-masing termasuk genus Methanosarcina dan Methanospirillum. Nilai konstanta pertumbuhan spesifik $(\mu)$ dari keempat isolat berkisar antara 0,022 - 0,031. Sedangkan efisiensi pembentukan gas metan untuk masing-masing isolat berkisar antara 53.4\%. - 67.6\%. Dari penelitian ini dapat disimpulkan bahwa isolat RB25 terpilih sebagai isolat yang memiliki konstanta pertumbuhan spesifik $(\mu)$ tertinggi yaitu 0,031 dan efisiensi produksi gas metannya $67,6 \%$.
\end{abstract}

Kata Kunci : biogas, irradiasi gamma, mikroba

\section{ABSTRACT}

SELECTION OF METHANOGENIC MICROBIAL BY GAMMA IRRADIATON ON IMPROVEMENT OF UNAEROBIC DIGESTION EFFICIENCY ON BIOGAS FORMATION. Selection of methanogenic microbial by gamma irradiation as an effort on improvement of efficiency process on biogas formation has been done. The objectives of this research is to obtain the methanogenic microbial isolate with high specific growth constant $(\mu)$, there for will be applicable for increasing the efficiency of biogas formation process. The microbial content sludge sample was taken from the digester tank conventional biogas installation located in Marangan village, Bokoharjo, Prambanan, Sleman and the sludge was irradiated using Co-60 gamma irradiator with varied dosage dose of 0-25 KGy. Microbial culture formation is conducted in growing media with 30\% liquid rumen content in un-aerob condition by addition of $80 \% \mathrm{H}_{2}$ and $20 \% \mathrm{CO}_{2}$ gas mixture. Analysis of colony growth was performed by observation using long-wave ultraviolet rays (UV rays), while the microbial growth was by spectro-photometric analysis. Determination of gas methane product was done using gas chromatographic method. The result shown that 4 isolated methanogenic microbial (RB10, $R B 15, R B 20$ and $R B 25)$ that grown on10-25 Kgy gamma irradiation. The identification result shows that isolate RB10 and RB25 are belong to Methanobacterium genus, while isolate RB15 and RB20 are belong to Methanosarcina and Methanospirillum genus respectively. The specific growth constant $(\mu)$ values of the 4 bacterial isolates are in the range between $0.022-0.031$. On the other hand, the efficiency of methane gas production for each isolates is in the range of $53.4 \%$. $-67.6 \%$. It can be concluded that isolate RB25 was the isolate with the highest specific growth constant $(\mu)$ value 0.031 and its efficiency of methane gas production was $67.6 \%$.

Keyword : biogas, gamma irradiation, microbial. 


\section{PENDAHULUAN}

adiasi gamma sudah lazim digunakan dalam proses sterilisasi karena dengan dosis yang relatif tinggi dapat Imematikan berbagai jenis mikroba seperti bakteri, archaea, jamur (kapang), atau bahkan virus. Bendabenda yang biasa disterilkan antara lain peralatan medis, obat-obatan, kosmetik, bahan pangan, jaringan biologi dan lain-lain. Dosis radiasi yang digunakan dalam proses sterilisasi akan tergantung kepada jenis bahan yang disterilkan, jenis mikroba, dan tingkat populasi mikroba. Perbedaan resistensi setiap jenis mikroba terhadap radiasi dapat digunakan juga sebagai dasar untuk melakukan seleksi terhadap jenis mikroba tertentu sesuai dengan kebutuhan. ${ }^{(1)}$

Perkembangan industri peternakan memang sangat dirasakan manfaatnya bagi masyarakat terutama dalam penyediaan protein hewani, namun juga menimbulkan dampak terhadap lingkungannya. Dengan menumpuknya limbah peternakan sampai dengan kapasitas tertentu akan menimbulkan dampak negatif antara lain berupa peningkatan populasi mikroba patogen sehingga mengakibatkan terjadinya pencemaran air tanah dan permukaan, pencemaran udara karena debu infektious serta bau yang kurang sedap. Di banyak negara berkembang, kotoran ternak, limbah pertanian, dan kayu bakar digunakan sebagai bahan bakar, sehingga menimbulkan polusi asap yang mengakibatkan gangguan kesehatan juga. Akhir-akhir ini mulai menjadi perhatian karena terjadinya emisi gas metan dan karbondioksida yang dikhawatirkan akan menyebabkan terjadinya efek rumah kaca, sehingga akan mempengaruhi perubahan iklim secara global. Proses digesti anaerob untuk pengolahan limbah peternakan tersebut dirasa akan memberikan beberapa keuntungan antara lain menurunkan nilai COD dan BOD, total solid, volatile solid, nitrogen nitrat, dan nitrogen organik. Di samping juga populasi bakteri coliform dan patogen, telur insekta, parasit dan bau relatif dapat diturunkan atau bahkan dihilangkan. ${ }^{(2)}$

Proses digesti anaerobik yang digunakan sebagai prinsip dasar pembuatan reaktor biogas merupakan proses pemecahan bahan organik oleh aktivitas mikrobia metanogenik dan asidogenik pada kondisi anaerob. Sebenarnya secara alami mikroba ini sudah terdapat di dalam limbah yang mengandung bahan organik tersebut, seperti kotoran hewan, manusia dan sampah organik lainnya.

Salah satu komponen utama biogas yaitu gas metana yang dibentuk oleh mikroorganisme methanogen yang secara taksonomis dimasukkan kedalam golongan Archaea methanogen. Archaea methanogen banyak terdapat di rawa-rawa, sedimen danau, sawah, moist landfills, saluran pencernaan hewan, dan kotoran ternak (sapi, kerbau, kuda, babi, kambing). Archaea merupakan salah satu kelompok prokariotik, yang dibedakan dengan bakteri karena tidak mempunyai membran luar tetapi mempunyai lapisan permukaan berupa sub unit protein atau glikoprotein yang ada di luar membran plasma, tidak memiliki peptidoglycan dalam dinding selnya tetapi mempunyai pseudomurein. Perbedaan lainnya terdapat ikatan ether-linked lipid dan RNA polimerase komplek, sedangkan bakteri mempunyai membran luar dan peptidoglycan dalam dinding selnya, Pada gambar 1 disajikan perbedaan susunan dinding sel bakteri dan archaea: ${ }^{(3,4,5)}$
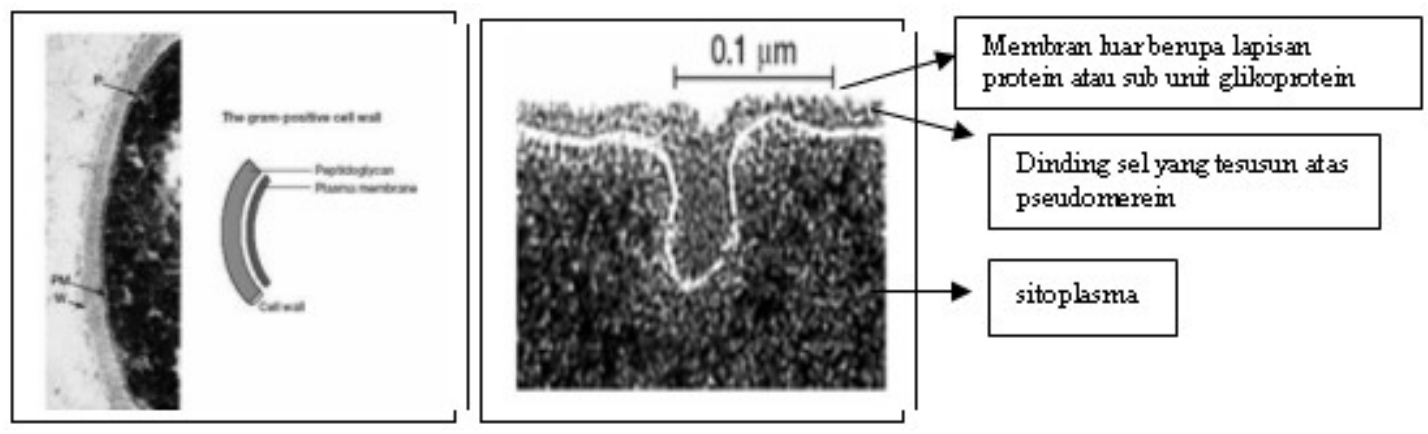

Gambar 1. Perbedaan Susunan Dinding Sel Bakteri dan Archaea

Susunan dinding sel yang unik menyebabkan archaea dapat ditemukan pada habitat yang sangat ekstrim seperti kondisi sangat kedap udara (strickly anaerob), salinitas tinggi (hypersaline), bahkan pada temperatur tinggi $\left(100{ }^{\circ} \mathrm{C}\right)$. Kelompok archaea sangat beraneka ragam baik dalam morfologi maupun fisiologi. Ada yang termasuk gram positif, gram negatif; dapat berbentuk spiral, batang, sarcina, bahkan bentuknya tak beraturan 
(pleomorphic); beberapa ada yang terdiri dari satu sel, ada yang berfilamen, berkumpul; dengan diameter 0,1 $15 \mu \mathrm{m}$ bahkan untuk yang berfilamen diameternya dapat mencapai $200 \mu \mathrm{m} .{ }^{(3,4)}$.

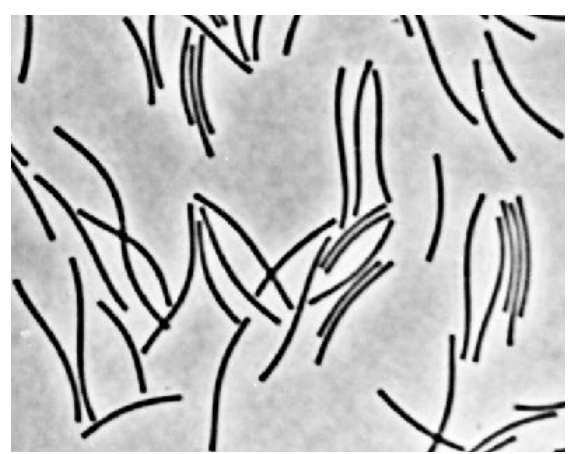

Gambar 2. Methanospirillum hungatei

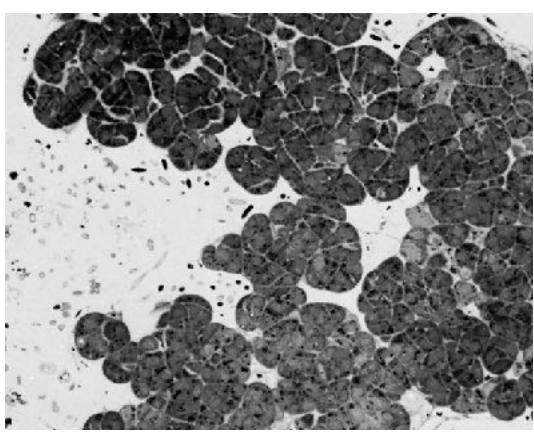

Gambar 4. Methanosarcina barkeri

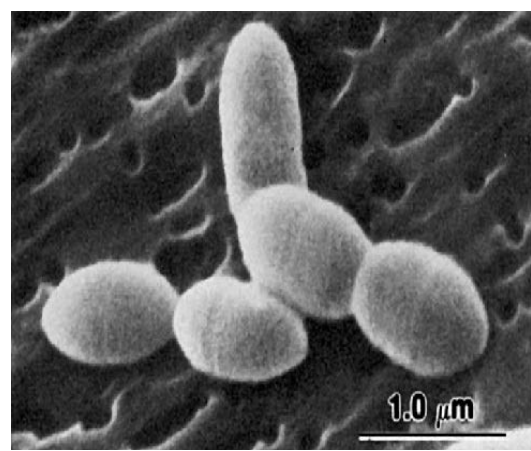

Gambar 3. Methanobrevibacter smithii

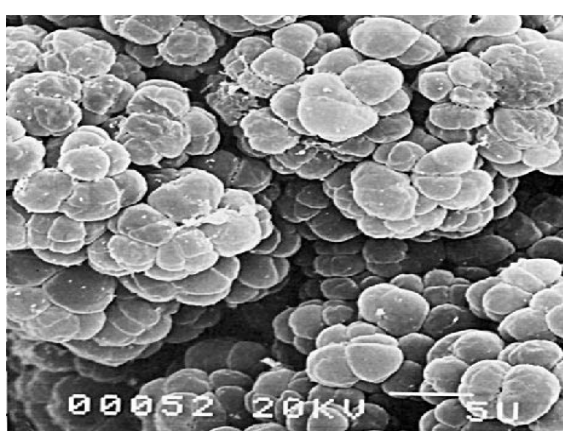

Gambar 5. Methanosarcina mazei

\section{Proses pembentukan biogas meliputi tiga tahap yaitu :}

1. Hidrolisis, pada tahap ini terjadi penguraian bahan-bahan organik mudah larut dan degesti bahan organik yang komplek menjadi lebih sederhana, perubahan struktur bentuk polimer menjadi bentuk monomer.

2. Pengasaman, pada tahap pengasaman komponen monosacharida yang terbentuk pada tahap hidrolisis akan menjadi bahan makanan bagi bakteri pembentuk asam. Produk akhir dari perombakan gula-gula sederhana ini yaitu asam asetat, propionat, format, laktat, alkohol, dan sedikit butirat, gas karbondioksida, hidrogen dan amonia.

3. Metanogenik, pada tahap metanogenik terjadi proses pembentukan gas metan. Tahapan proses pembentukan biogas disajikan pada Gambar 6. ${ }^{(6)}$

Jenis mikroba yang terlibat dalam proses anaerobik ini bersifat hidrolitik yang memecah bahan organik menjadi gula dan asam amino, fermentatif yang mengubah gula dan asam amino tadi menjadi asam organik, asidogenik mengubah asam organik menjadi hidrogen, karbondioksida dan asam asetat serta metanogenik yang menghasilkan metan dari asam asetat, hidrogen dan karbondioksida. Optimasi proses biogas dapat dilakukan antara lain dengan seleksi mikroba yang digunakan serta dijaga agar selalu dalam fase logaritmik, penyempurnaan desain digester dan pengaturan suhu operasi serta pemilihan bahan dasar biomasa lignoselulosa termasuk perlakuan awalnya. 


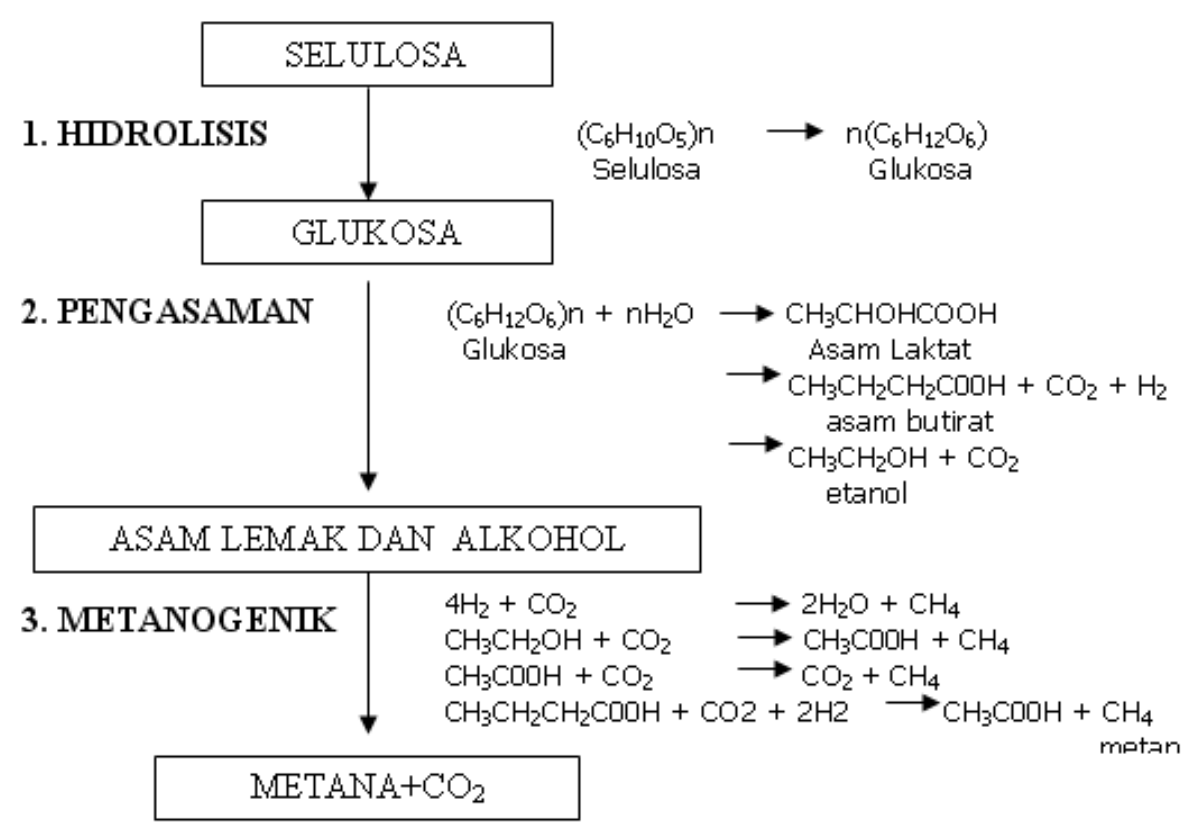

Gambar 6. Tahapan Proses Pembentukan Biogas

Dewasa ini, masyarakat pedesaan telah menggunakan biodigester untuk mengubah limbah pertanian dan peternakan yang mereka miliki menjadi bahan bakar gas, pada skala rumah tangga atau komunitas. Beberapa keuntungan biodigester antara lain : mengurangi penggunaan bahan bakar lain (minyak tanah, kayu, dsb), menghasilkan pupuk organik berkualitas tinggi, mengurangi pemanasan global akibat efek rumah kaca dari gas metan yang terlepas ke lingkungan dan meningkatkan kualitas udara karena mengurangi asap dan jumlah karbodioksida akibat pembakaran bahan bakar minyak/kayu bakar.

Di Negara berkembang, biogas merupakan suatu hasil samping dari pengolahan limbah peternakan yang telah membawa keuntungan untuk kesehatan, sosial, lingkungan secara finansial. Dalam laporan UNDP 1997, Energy After Rio: Prospect and challengers, mengidentifikasi bahwa instalasi biogas adalah satu penyedia sumber energi desentralisasi yang sangat berguna. Tidak seperti teknologi penyedia energi yang tersentralisasi seperti pembangkit tenaga listrik yang berasal dari sumber tenaga hidroelektrik, batu bara, minyak atau gas alam. Untuk membuat instalasi biogas tidak memerlukan modal yang terlalu besar dan tidak menimbulkan masalah lingkungan bahkan merupakan solusi dari masalah lingkungan itu sendiri, juga memberikan beberapa keuntungan lainnya, selama limbah organik dan air tersedia maka instalasi biogas dapat dibangun.

Beberapa Negara telah membuat program biogas dalam skala besar, Tanzania misalnya, membuat model berdasarkan integrasi recoveri sumber bahan baku yang berasal dari limbah kota dan industri untuk menghasilkan tenaga listrik dan pupuk. Produksi biogas dalam skala kecil sudah umum dilakukan di pedesaan terutama di Cina dan India. Pada akhir tahun 1993, sekitar seperlima sampai seperempat juta petani telah mempunyai digester biogas, dengan produksi metan sekitar 1,2 miliar $\mathrm{m}^{3}$ per tahun. Di India, teknologi biogas telah berkembang dan didiseminasikan secara luas untuk memenuhi kebutuhan energi di pedesaan, contohnya untuk pompa irigasi dan listrik. Sampai saat ini telah dibangun lebih dari 2 juta digester dan menyumbangkan hampir 200.000 pekerjaan tetap..$^{(7)}$

Akibat dari promosi renewable energy melalui aksi politik di tahun 1980 dan 1990 an, Denmark telah maju di garis depan untuk pengembangan, pemasaran, dan ekspor renewable energy yang berasal dari angin dan biomassa. Sekarang negara-negara Eropa lainnya telah mengambil alih peran ini, Jerman misalnya, merupakan pasar yang sangat berkembang untuk produksi renewable energy. Di Jerman, produksi biogas merupakan salah satu yang paling pesat dalam produksi renewable energy dan diharapkan akan di bangun beberapa ratus konstruksi biogas. ${ }^{(8)}$ 
Teknologi produksi biogas dari kotoran ternak untuk pemenuhan kebutuhan energi alternatif bagi masyarakat pedesaan memang sudah banyak dikenal saat ini, namun masih terbuka peluang untuk peningkatan efisiensi proses digesti anaerob yang terjadi serta dapat dilakukan percepatan proses produksinya.

Dalam penelitian ini, seleksi mikroba dilakukan menggunakan irradiasi gamma dengan dosis yang bervariasi, hal ini didasarkan bahwa perbedaan resistensi berbagai jenis mikroba terhadap radiasi, sehingga diharapkan pada dosis tertentu dapat dipilih jenis mikroba yang sesuai dengan fenotip yang dikehendaki untuk dibuat isolat / kultur murni sehingga dapat diaplikasikan pada proses produksi biogas tersebut.

\section{METODOLOGI}

\section{Bahan Yang Diperlukan}

Alkohol $70 \%$, sludge digester anaerob, spritus, gas campur ( $80 \% \mathrm{H}_{2}$ dan $20 \% \mathrm{CO}_{2}$ ), media isolasi dan media pertumbuhan yang terdiri dari : cairan rumen sapi, mineral $1\left(\mathrm{~K}_{2} \mathrm{HPO}_{4}\right)$, mineral $2\left(\mathrm{KH}_{2} \mathrm{PO}_{4},\left(\mathrm{NH}_{4}\right)_{2} \mathrm{SO}_{4}\right.$, $\mathrm{NaCl}, \mathrm{MgSO}_{4}, \mathrm{CaCl}_{2}$ ), trypticase, resazurin, cysteine hydrochloride, agar murni (oxoid), dan aquadest. Untuk karakterisasi mikroba menggunakan cat gram (A,B,C,D), medium SIM (Sulfur Indol Motility).

\section{Peralatan Yang Digunakan}

Ose, Drigalski, bunsen, petridish, tabung hungate, hot plate, autoklaf, erlenmeyer, pipet, mikropipet dan tip pipet, mikroskop cahaya, kamera digital, shaker, syringe, jarum, laminar air flow (LAF), anaerobic jar, rak tabung, sentrifuge, tabung sentrifuge, spektrofotometer, tabung kuvet, magnetic stirrer, alumunium foil, kapas, karet, haemocytometer.

\section{Cara Kerja}

\section{Sampling dan Irradiasi Sampel}

Sampel di ambil dari digester anaerob yang berada di desa Marangan, Bokoharjo, Prambanan, Sleman, Yogyakarta. Sampel dimasukkan ke dalam tabung reaksi, kemudian sampel dimasukkan ke dalam tabung jar yang sudah disterilisasi dan diberi gaspack. Sampel dibawa ke PATIR-BATAN Jakarta untuk dirradiasi menggunakan Irradiator Gamma $\mathrm{Co}^{60}$ dengan variasi dosis 0-25 KGy.

\section{Isolasi dan Karakterisasi}

Sampel yang telah diirradiasi ditanam pada media agar, di suntikkan campuran gas $\left(80 \% \mathrm{H}_{2}\right.$ dan $20 \%$ $\mathrm{CO}_{2}$ ) ke dalam jar, kemudian diinkubasi selama 25 hari. Dilakukan pengamatan setiap 2 hari sekali dengan mengunakan sinar UV gelombang panjang. Archea methanogen akan mengeluarkan pendar saat diletakkan di bawah sinar UV. Bakteri methanogen yang ditemukan, diisolasi sebagai biakan murni dan dikarakterisasi. Karakterisasi meliputi Uji Morfologi (bentuk sel, elevasi, bentuk koloni, tepi koloni,dan pertumbuhan dalam agar slant), Pengecatan gram, dan Uji Motilitas. ${ }^{(8,9)}$

\section{Pembuatan Kurva Pertumbuhan}

Koloni mikroba diinokulasikan ke dalam media cair, disuntikkan campuran gas $\left(80 \% \mathrm{H}_{2}\right.$ dan $\left.20 \% \mathrm{CO}_{2}\right)$ dan diinkubasi di dalam jar anaerob selama 24 jam yang selanjutnya disebut starter. Diambil 0,7 ml dimasukkan ke dalam media cair, diinkubasi pada suhu $37^{\circ} \mathrm{C}$. Kemudian OD (Optical Density) dibaca dengan spektrofotometer pada panjang gelombang $660 \mathrm{~nm}$ setiap 3 jam selama 60 jam.

\section{Identifikasi Isolat}

Identifikasi isolat mikroba antara lain dilakukan dengan pengamatan morfologi koloni dan bentuk sel, pengecatan gram dan pengujian biokimia. Penentuan genus dilakukan dengan metode Matching profile berdasarkan Bergey's Manual of Determinative Bacteriology gth $^{\text {th }}$ edition. ${ }^{\left({ }^{9}\right)}$

\section{Pengujian efisiensi pembentukan gas metan dengan GC (Gas Chromatography)}

Pengujian dengan GC dilakukan dengan menanam isolat dalam medium broth. Tabung yang berisi isolat dishaker selama 14 hari, dilakukan penyuntikan campuran gas kedalam tabung setiap 2 hari sekali. Setelah 14 hari dilakukan pengukuran kadar metannya. 


\section{HASIL DAN PEMBAHASAN}

Sampel diambil dari dalam tangki digester instalasi biogas konvensional yang berada di Desa Marangan, Bokoharjo, Prambanan, Sleman, Yogyakarta. Sampel dimasukkan ke dalam tabung berleher pendek dengan ukuran $16 \times 150 \mathrm{~mm}$ dengan tutup karet pada bagian dalam dan tutup ulir pada bagian luar. Kemudian sampel dimasukkan ke dalam tabung jar yang sudah difiksasi dengan alkohol, disterilkan dengan UV (ultra violet), dan diberi gaspack. Irradiasi dilakukan di PATIR BATAN Jakarta menggunakan sinar gamma dengan variasi dosis 0-25 kGy. Sampel yang telah diirradiasi ditanam pada media pertumbuhan di dalam petridish dan diamati pertumbuhan koloninya. Pengamatan pertumbuhan archea metanogenik dilakukan dengan teknik penyinaran menggunakan UV gelombang panjang. Hasil pengamatan tersebut disajikan pada Tabel 1.

Tabel 1. Hasil Pengamatan Pertumbuhan Archea Metananogen Menggunakan UV Gelombang Panjang

\begin{tabular}{|r|l|c|c|c|c|c|c|}
\hline \multirow{2}{*}{ No } & \multirow{2}{*}{ DOSIS } & \multicolumn{5}{|c|}{ PERTUMBUHAN KOLONI HARI KE } & \multirow{2}{*}{ KETERANGAN } \\
\cline { 3 - 7 } & & 2 & 4 & 6 & 8 & 10 & \\
\hline \hline 1 & 0 & - & - & - & - & - & - \\
\hline 2 & $100 \mathrm{~Gy}$ & - & - & - & - & - & - \\
\hline 3 & $300 \mathrm{~Gy}$ & - & - & - & - & - & - \\
\hline 4 & $600 \mathrm{~Gy}$ & - & - & - & - & - & - \\
\hline 5 & $1.0 \mathrm{KGy}$ & - & - & - & - & - & - \\
\hline 6 & $1.5 \mathrm{KGy}$ & - & - & - & - & - & - \\
\hline 7 & $5.0 \mathrm{KGy}$ & - & - & - & - & - & - \\
\hline 8 & $10 \mathrm{KGy}$ & Tumbuh & Tumbuh & Tumbuh & Tumbuh & Tumbuh & RB10 \\
\hline 9 & $15 \mathrm{KGy}$ & - & Tumbuh & Tumbuh & Tumbuh & Tumbuh & RB15 \\
\hline 10 & $20 \mathrm{KGy}$ & Tumbuh & Tumbuh & Tumbuh & Tumbuh & Tumbuh & RB20 \\
\hline 11 & $25 \mathrm{KGy}$ & Tumbuh & Tumbuh & Tumbuh & Tumbuh & Tumbuh & RB25 \\
\hline
\end{tabular}

Tabel 1. menunjukkan bahwa irradiasi gamma cukup efektif digunakan untuk seleksi pertumbuhan mikroba. Irradiasi pada dosis 0-5 KGy tidak terjadi pertumbuhan archea metanogenik sedangkan pada dosis 10 , 20 dan $25 \mathrm{KGy}$, bakteri metanogenik mulai tumbuh pada hari ke 2 dan dosis $15 \mathrm{KGy}$ hari ke 4 . Hal tersebut dapat terjadi karena sampel yang diirradiasi pada dosis $\geq 10 \mathrm{KGy}$, kompetitor yang mengganggu pertumbuhan bakteri metanogenik mati sehingga archea metanogenik dapat tumbuh dengan baik, yang ditandai dengan timbulnya bercak-bercak putih pada media dan pada saat diidentifikasi dengan sinar ultra violet (UV) gelombang panjang berpendar biru kehijauan, seperti ditunjukkan pada Gambar 7 .

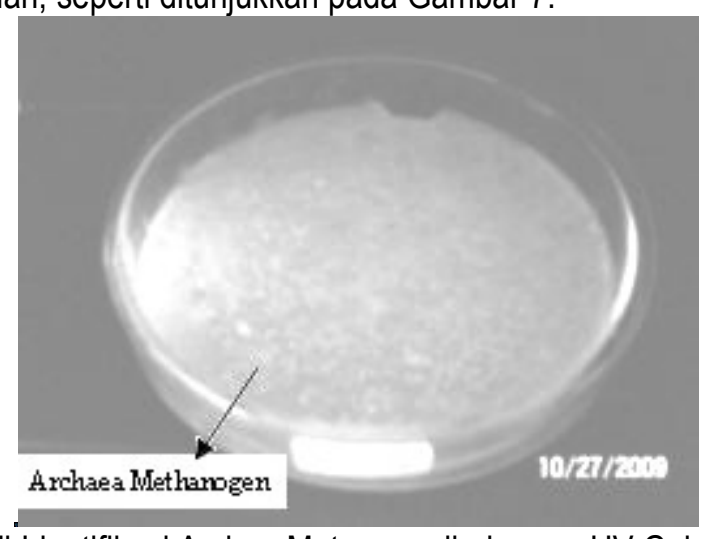

Gambar 7. Hasil Identifikasi Archea Metanogenik dengan UV Gelombang Panjang

Karakterisasi yang dilakukan meliputi uji fenotipik (bentuk sel, elevasi, bentuk koloni, tepi koloni dan pertumbuhan dalam agar slant), pengecatan gram dan Uji Motilitas. Hasil pengujian karakterisasi RB10, RB15, RB20 dan RB25 disajikan pada Tabel 2. Karakterisasi dan identifikasi isolat dimaksudkan untuk mengetahui sifat-sifat spesifik dari setiap isolat, yang pada akhirnya dapat digunakan untuk menentukan status taksonomis dari isolat tersebut. 
Seleksi Mikroba Metanogenik Menggunakan Irradiasi Gamma Untuk Peningkatan Efisiensi Proses Digesti Anaerob Pembentukan Biogas (M. Yazid, Aris bastianudin)

Tabel 2. Hasil Uji Karakterisasi Isolat Archea

\begin{tabular}{|c|l|c|c|c|c|c|c|c|l|}
\hline No & Ilsolat & $\begin{array}{c}\text { Penge } \\
\text { catan } \\
\text { Gram }\end{array}$ & Uji Motilitas & Bentuk sel & Elevasi & $\begin{array}{c}\text { Bentuk } \\
\text { koloni }\end{array}$ & $\begin{array}{c}\text { Tepi } \\
\text { koloni }\end{array}$ & $\begin{array}{c}\text { Pertumb. } \\
\text { dalam agar } \\
\text { slant }\end{array}$ & \multirow{2}{*}{ Keterangan } \\
\hline \hline 1. & RB10 & + & Non motil & Batang & Convek & Circular & Entire & Effuse & Methanobacterium \\
\hline 2. & RB15 & + & Non motil & Sarcina & Raised & Irregular & Undulate & Filiform & Methanosarcina \\
\hline 3. & RB20 & - & Motil & Spirillum & Raised & Irregular & Undulate & Filiform & Methanospirillum \\
\hline 4. & RB25 & + & Non motil & Batang & Convek & Circular & Entire & Filiform & Methanobacterium \\
\hline
\end{tabular}

Dari sifat-sifat spesifik yang disajikan pada Tabel 2 dapat diketahui bahwa tiga isolat RB10 dan RB20 termasuk bakteri gram positif dengan bentuk batang dan tepi koloni entire, RB15 termasuk gram positif dengan bentuk sarcina dan tepi koloni undulate sedangkan RB25 termasuk bakteri gram negatif dengan bentuk spirillum dan tepi koloni undulate. Menurut Bergey's Manual of Determinative Bacteriology maka hasil uji karakterisasi pada Tabel 2, dapat menentukan genus dari isolat bakteri tersebut, yaitu isolat RB10 dan RB25 merupakan anggota dari genus Methanobacterium. Sedangkan isolat bakteri RB15 merupakan anggota dari genus Methanosarcina dan RB 20 termasuk genus Methanospirillum.

Untuk mendapatkan isolat yang memiliki kemampuan tinggi dalam pembentukan gas metan, dilakukan seleksi terhadap keempat isolat yang didapatkan pada tahap isolasi. Selanjutnya dipilih isolat yang memiliki pertumbuhan terbaik yaitu isolat bakteri dengan konstanta kecepatan pertumbuhan spesifik $(\mu)$ tertinggi dengan cara menginokulasikan isolat bakteri metanogenik ke dalam media cair yang mengandung $30 \%$ cairan rumen yang disuntikkan campuran gas $\left(80 \% \mathrm{H}_{2}\right.$ dan $\left.20 \% \mathrm{CO}_{2}\right)$ dan diinkubasi di dalam jar anaerob selama $24 \mathrm{jam}$. Pertumbuhan koloni diamati dengan mengukur OD (Optical Dencity) menggunakan spektrofotometer pada panjang gelombang $660 \mathrm{~nm}$ setiap 3 jam selama 60 jam. Adapun hasil seleksi tersebut disajikan pada Gambar 8.

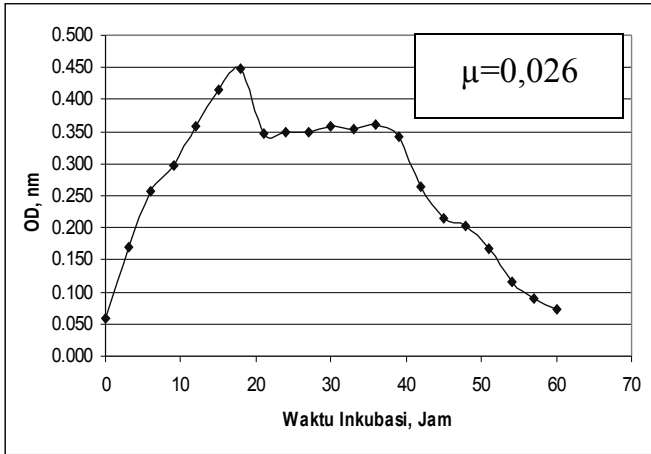

Gambar 8a. Pertumbuhan Isolat RB10

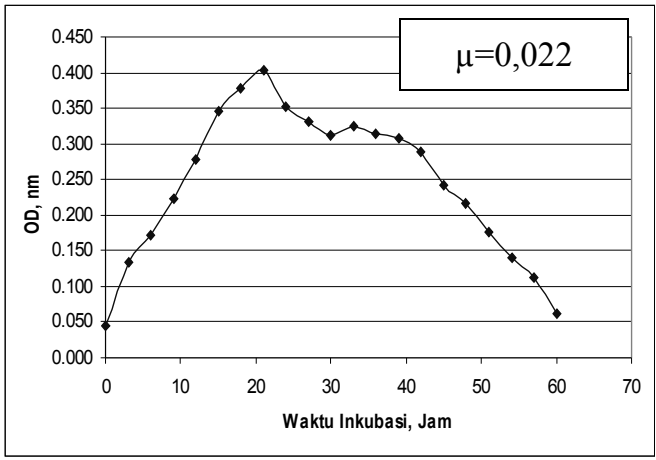

Gambar 8c. Pertumbuhan Isolat RB20

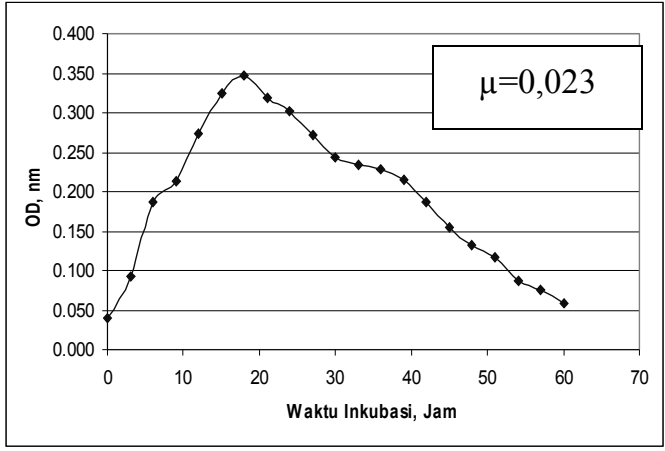

Gambar 8b. Pertumbuhan Isolat RB15

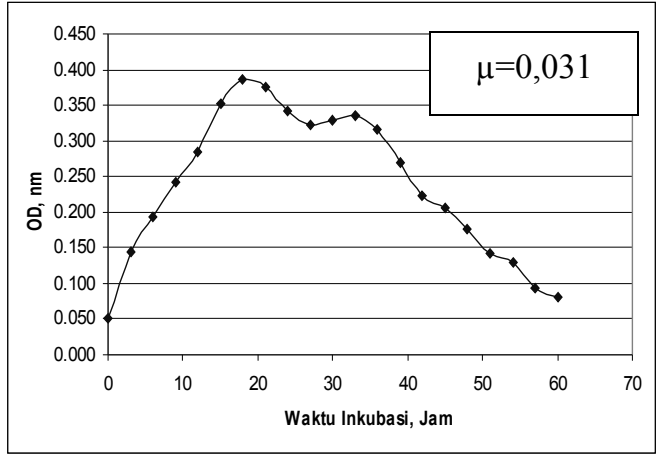

Gambar 8d. Pertumbuhan Isolat RB25 


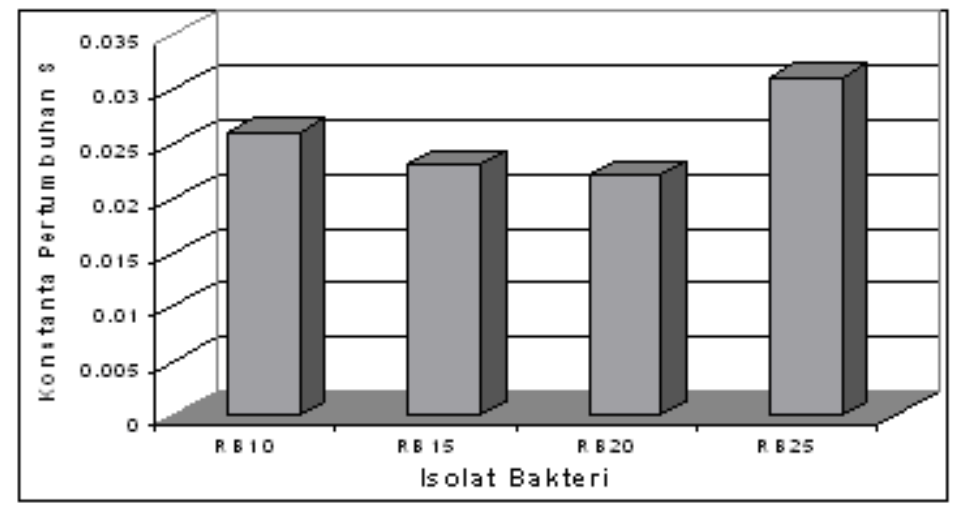

Gambar 9. Konstanta Pertumbuhan Spesifik ( $\mu$ ) Isolat Mikroba Hasil Irradiasi

Dari Gambar 9 dapat diketahui bahwa konstanta pertumbuhan spesifik $(\mu)$, RB25>RB10>RB15>RB20 yaitu $0.031>0.026>0.023>0.022$. Hal tersebut menunjukkan bahwa isolat mikroba RB25 lebih cepat pertumbuhannya dibandingkan dengan ketiga isolat lain dengan demikian diharapkan isolat RB25 dapat memberikan unjuk kerja yang lebih baik dalam proses pembentukan metan dalam produksi biogas. Hasil pengujian efisiensi pembentukan gas metan disajikan pada Gambar 10.

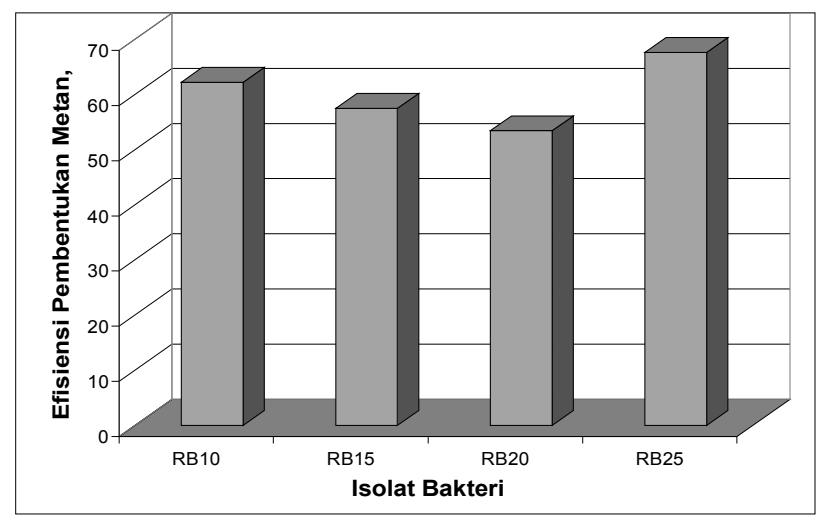

Gambar 10. Efisiensi Pembentukan Gas Metan Isolat Mikroba Hasil Irradiasi

Dari Gambar 10 dapat diketahui bahwa efisiensi pembentukan gas metan dari keempat isolat RB25>RB10>RB15>RB20 yaitu $67.6 \%>62.2 \%>57.5 \%>53.4 \%$. Hal tersebut menunjukkan bahwa isolat RB25 lebih baik kinerjanya pada pembentukan gas metan dibandingkan dengan ketiga isolat lain.

\section{KESIMPULAN}

1. Dosis efektif untuk seleksi pertumbuhan archea methanogenic berkisar antara 10-20 kGy, sehingga diperoleh 4 isolat archea methanogenic yaitu RB10, RB15, RB20 dan RB25.

2. Hasil identifikasi mengindikasikan bahwa isolat RB10 dan RB25 merupakan anggota dari genus Methanobacterium, sedangkan isolat RB15 dan RB20 masing-masing merupakan anggota dari genus Methanosarcina dan Methanospirillum

3. Isolat RB25 terpilih sebagai isolat yang mempunyai konstanta pertumbuhan spesifik $(\mu)$ tertinggi sebesar 0.031 sekaligus efisiensi pembentukan gas metannya sebesar $67.6 \%$.

\section{DAFTAR PUSTAKA}

1. http://www.infonuklir.com/modules/news/index.php?storytopic=26, diakses tanggal 16 Maret 2010

2. GHOSE, T.K., Bioconversion of organic residues :Methane from integrated biological systems. http/l:www. unu. edu/unupress/food/8f023e/ 8FO23EO6.htm. (1980) 
3. ZEHNDER, A.J.B. et al., Microbiology of Methane Bacteria in Anaerobic Digestion. Elesvier Biomedical Press. Amsterdam (1982).

4. MADIGAN, M.T \& Martinko, et al.,. Brock Biology of Microorganisms. $12^{\text {th }}$ Edition. San Fransisco : Pearson Benjamin Cummings (2009)

5. PRESSCOT, L.M. \& HARLEY, J.P.et al.,...Microbiology $5^{\text {th }}$ Edition. New York : Mc Graw-Hill Copanies, Inc. (2002)

6. NURTJAHYA et al., Pemanfaatan limbah ternak ruminansia untuk mengurangi pencemaran lingkungan. Makalah Pengantar Falsafah Sains. Program Pascasarjana Institut Pertanian Bogor. (2003,)

7. KAROTTKI, R. dan G.B. OLESEN.. Biogas in India : A Sustainable Energy Success Story. http://www.ecouncil. ac.cr/rio/focus/report/ english/inforse.htm. (1977)

8. BOUWMAN AF.. Exchange of greenhouse gases between terrestrial ecosystems and the atmosphere. In Bouwman AF (Ed.), Soils and the Greenhouse Effects. John Wiley \& Sons, Chichester, New York, Brisbane, Toronto, Singapore. (1990)

9. HOLT, J.G. \& KREG, R.N., et al.,. Bergeys Manual of Determinative Bacteriology $9^{\text {th }}$ Edition. Philladhelpia: Lippincot Williams \& Wilkins USA (2000.) 